\title{
Effect of Climate Change on Soil Health and Implications on Food Security: A Review
}

\author{
Wycliffe Tumwesigye 1, 2,*, Bobe Bedadi 1,3, Johnson Atwiine ${ }^{4}$
}

${ }^{1}$ African Center of Excellence for Climate Smart Agriculture and Biodiversity Conservation; Haramaya University, P.O. Box 138, Dire Dawa, Ethiopia.

2 Department of Agriculture, Agribusiness and Environmental Sciences, Bishop Stuart University, Mbarara, Uganda

${ }^{3}$ College of Agriculture and Environmental Sciences Haramaya University P.O. Box 138, Dire Dawa, Ethiopia

${ }^{4}$ Department of Economics and Statistics, Bishop Stuart University, P.O Box 09, Mbarara, Uganda

${ }^{*}$ Corresponding author email: wtum2012@gmail.com

DOI: https://doi.org/10.34256/irjmt2136

Received: 08-03-2021, Revised: 05-05-2021, Accepted: 07-05-2021, Published: 11-05-2021

Abstract: Climate change and soil health are intertwined complex processes that affect each other. The aim of this review was to find out the impact of climate change on soil health, its implication on food security and human welfare across the globe. The study found out that soil health is affected by land use practices and several anthropogenic activities carried out on landscapes; climate change and variability. Soil health also contributes to soil water retention, crop productivity, households' food and income security culminating into a large contribution towards achieving sustainable development goals across the globe. Soil components affect climate and climate affects soil health and human wellbeing. The review article concluded that climate change and soil health are complex and intertwined multidisciplinary processes that require multidisciplinary approaches for better understanding and improvement of crop production. Appropriate climate smart agricultural practices are recommended to enhance soil health and mitigate and adapt to the changing climate for the improved farmers' income, food security and human wellbeing across the globe.

Keywords: Soil health, Climate change, Food security, Crop production, Climate smart agriculture

\section{Introduction}

Climate change and soil health are closely interlinked, influence each other and food security globally. Climate change refers to the change in climate variables for a long period of time, usually 30 years or more [1]. The major variables of climate change being temperature and precipitation. Soil health is the ability of soil to perform various functions for the welfare of biodiversity and humanity. Figure 1 shows the three major processes affecting soil health. These include:physical, chemical and biological [2]. These processes influence the soil structure, nutrient-holding capacity and nitrogen mineralization among others. To better understand interaction of soil health and climate change, one needs to look at indicators that relate soil physical, chemical and biological properties to ecological functions and which can be monitored in the context of sustainable land management and climate change [3]. A healthy soil supports species diversity (flora, fauna and microorganisms), which in turn support crop production and human welfare. Climate smart soils are healthy in nature and provide ecosystem services required for humans and their environment [4]. Soils in the tropics are more healthy, fertile and have deeper profile than soils in the temperate regions thus the former provides better requirements to support biodiversity at all levels (gene, species and ecosystem) [5]. Soils in the tropics are reported to be more developed with more horizons than soils in the temperate regions [6]. This is due the differences in temperature and moisture in the two landscapes. High temperature and heavy precipitation significantly affect soil health and healthy soils sequester more carbon (in form of soil organic carbon) and mitigate climate change. Heavy rainfall results into flooding, erosion and landslides that affect the soil structure hence its ability to support life [5]. Moreover, soil erosion washes away the top soil together with its nutrients that support plant growth and crop production for human survival. Heavy rains also enhance nutrient leaching which makes nutrients unavailable to plant utilization and assimilation hence poor plant growth and productivity. 


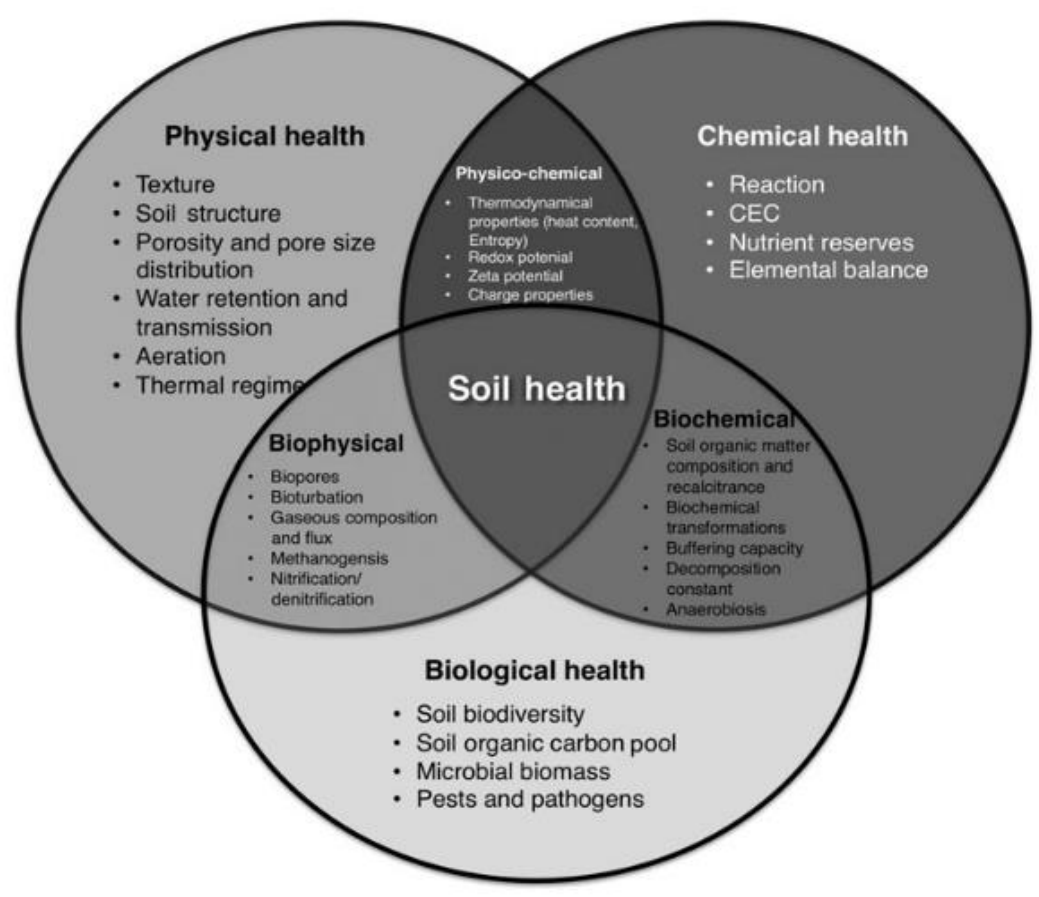

Figure 1. Soil health components (source: Bhupinder et al, 2011)

Previous studies reported that soil organic matter, a proxy for soil health, increases with precipitation and decrease with increase in temperature hence affecting soil health [6-10]. Consequently, climate change directly affects the soil health and its ability to support biodiversity and food production. The effect of climate change on soil health is poorly documented hence the need for this review. The literature review focuses on the following objectives: the effect of climate change on soil formation; the effect of land management on soil health; the effect of climate change on soil chemistry; the effect of climate change on soil and ground water availability; the synergy between soil health, crop production and food security; the linkage between soil health and climate smart agriculture; the effect of Climate change on soil biodiversity; the contribution of soil health to Sustainable Development Goals (SDGs); and the strategies for improving soil health for improving crop production.

\section{The Effect of Climate Change on Soil Formation}

Climate affects soil formation and soil structure [11]. Healthy soils have appropriate levels of nutrients necessary for the production of healthy plants, moderately high levels of organic matter, a soil structure with good aggregation of the primary soil particles \& macro-porosity, moderate $\mathrm{pH}$, thickness sufficient to store adequate water for plants, a healthy microbial community, and absence of elements or compounds in concentrations toxic for plant, animal, and microbial life [12]. High temperature breaks down the soil structure, reduced the ability for soil water retention and dissociates soil particles which making soil less productive and effectively support living organisms [13]. Warmer and wetter topical conditions have deeper and healthier soils than drier and colder temperate regions. Tropical soils, though healthier, have higher leaching of minerals and clay compared to the temperate soils. They require efficient management practices to keep them healthier and produce more crop yields for the populations [6]. At the same time, heavy rains result into compact soils that do not favour soil microorganisms thus making it unfavourable for their survival and soil respiration. Studies done in China revealed that Mineral-associated organic carbon (MOC), is dependent on soil type, soil texture and climate [14]. Soil organic carbon is used as an indicator for soil health and the higher the SOC, the healthier is the soil [8] and high temperature affects soil moisture and SOC [15] and soil structure.

\section{The Effect of Land Management on Soil Health}

Land management and agricultural practices affect soil health and climate change [16-17]. Slash and burn, for instance, destroys the soil structure, evaporates soil moisture and releases greenhouse gasses to the atmosphere thus enhancing climate change [18]. Additionally, heavy tillage destroys soil structure, decreases soil bulk density and exposes soils 
to soil erosion agents such as wind and water thereby undermining soil productivity in a given agricultural landscape [19]. This is exacerbated by slopping agricultural landscapes where water erosion is facilitated by the slope. All soil processes can be affected by the type of land management practice [20]. Research conducted in the US, projected that growing biofuels on former corn large fields will increase greenhouse gases by $50 \%$ thus enhancing climate change [21]. Large scale production of biofuels attempts to reduce the impact of climate change by utilization of environmentally friendly energy source, but contrary to the intention of the operation, climate change is instead promoted.

\section{The Effect of Climate Change on Soil Chemistry}

Intensive agriculture results into loss of soil organic matter, mostly in tropical soils. The Soil Organic Carbon loss is usually due to climate change and management practices [22-23]. Climate change affects soil chemistry and several soil properties that are important for crop production [24-25]. Studies in Finland reported that reclamation of acid sulphate (AS) soils for agriculture resulted into increased metal cations that may expose the human population to increased metal intake. Mean $\mathrm{Fe}, \mathrm{Cr}, \mathrm{Cu}, \mathrm{Zn}$ as well as $\mathrm{C}$ and $\mathrm{N}$ concentrations were higher in AS soils than their counterpart soils in the same region. This poses a threat to human health because swallowing heavy metals like Cr may cause diseases [21]. Further, study conducted in Canada revealed that increased temperature decreases SOC while increasing soil microbial activity [26]. Type of cultivated crop also affect the nutrient cycle in soil such as leguminous green manure cropping systems were found to increase nitrogen concentration and improve soil health [27]. However, previous research pointed out that the risk of nitrate leaching in crops fertilized with minerals or organic $\mathrm{N}$ is weather and soil dependent and this affects crop productivity [28].

\section{The Effect of Climate Change on Soil and Ground Water Availability}

Climate change is reported to have significant impact on availability of ground water in soils, which is important for plant growth and people's livelihood [2930]. Increased temperatures cause by climate change in different climate scenarios, especially, Representative Concentration Pathway (RCP), RCP6.0 and RCP8.5 will negatively affect ground water availability and this will affect crop production, livestock and human lives [31]. Ground water deficiency affects plant growth and this in turn affect fauna species that depend on them for their feeding [24]. Rivers and lakes will decrease in their levels hence undermining irrigation systems for crop production. Simply put, reduction of ground water caused by climate change affects several ecosystems and food webs including humans [32].

Interaction of climate change, soil processes, plant primary production and land management at different intensities and magnitude affect soil health and crop production [33]. Details of possible impact of climate change on soil health indicators are provided in Table 1.

Table 1. Effect of climate change on soil health indicators

\begin{tabular}{|c|l|}
\hline Soil Heath Indicators & \multicolumn{1}{|c|}{ Climate Change Effect } \\
\hline Biological & \multicolumn{1}{|c|}{} \\
\hline Soil organic matter (SOM) & $\begin{array}{l}\text { High temperature affects soil moisture, Soil organic matter and soil structure [15]. } \\
\text { Soil Organic matter increases microbial biomass and catabolic activity which may } \\
\text { directly enhance nutrient mineralization and SOM stabilization [10] }\end{array}$ \\
\hline Respiration & $\begin{array}{l}\text { Increase in annual maximum and minimum temperature increased microbial } \\
\text { respiration [26] hence releasing more greenhouse emissions to the atmosphere } \\
\text { and further increasing climate (positive feedback) }\end{array}$ \\
\hline Soil biota biomass & $\begin{array}{l}\text { Microbial growth and activity generally decrease with decreased temperature. } \\
\text { Extremely high temperatures, in general, are dangerous for many microorganisms } \\
{[24] \text { and affect their respiration, growth and biomass production. }}\end{array}$ \\
\hline Microbial biomass C \& N & $\begin{array}{l}\text { Increase in annual maximum and minimum temperature decreases SOC stocks } \\
{[26] \text { and decreases N leaching }}\end{array}$ \\
\hline Potentially mineralizable & $\begin{array}{l}\text { Increasing temperatures increase N mineralization thus have a positive effect on } \\
\text { plant growth [8] and food production }\end{array}$ \\
\hline $\mathrm{N}$ & $\begin{array}{l}\text { Extreme high temperature denatures enzymes activity and very low temperature } \\
\text { make enzymes inactive to support soil productivity and plant life. Moderate } \\
\text { temperature required for maintaining healthy soils [21]. }\end{array}$ \\
\hline \multicolumn{2}{|c}{ Enzyme activity }
\end{tabular}




\begin{tabular}{|c|c|}
\hline Chemical & \\
\hline $\begin{array}{l}\mathrm{pH} \text {; rate of acidification or } \\
\text { alkalization }\end{array}$ & $\begin{array}{l}\text { Low pH leads to plant nutrient deficiency and unavailability except for } \mathrm{Al} \text { and } \mathrm{Mn} \text { to } \\
\text { plant use and high } \mathrm{pH} \text {, the solubility of many metals and trace elements is } \\
\text { decreased, including essential nutrients for plants such as } \mathrm{Fe}, \mathrm{Mn}, \mathrm{Cu} \text { or } \mathrm{Zn} \text { [34]. } \\
\text { Soil pH affects soil water retention capacity namely by impacting the biological and } \\
\text { physical processes of the soil [35] and climate affects soil pH }\end{array}$ \\
\hline Electrical conductivity & $\begin{array}{l}\text { Soil electrical conductivity (EC) is a measure of the amount of salts in soil. High } \\
\text { temperature interferes with soil microbial activity and affects EC of the soil [36] }\end{array}$ \\
\hline $\begin{array}{l}\text { leachable salts Adsorption } \\
\text { \& cation exchange } \\
\text { capacity }\end{array}$ & $\begin{array}{l}\text { Heavy rains increase nutrients leaching and make them less available to crop } \\
\text { growth and food production [28]. }\end{array}$ \\
\hline Plant available $\mathrm{N}, \mathrm{P}, \mathrm{K}, \mathrm{S}$ & $\begin{array}{l}\text { Heavy rainfall causes nutrient leaching to far deep soil layers beyond which crops } \\
\text { can reach them hence causing less crop production and reduced yields. Plants } \\
\text { with no tap root system will also not reach the leached nutrients thus poor growth } \\
\text { [8]. }\end{array}$ \\
\hline \multicolumn{2}{|r|}{ S } \\
\hline Porosity & $\begin{array}{l}\text { High temperature may result into large porosity with low specific areas resulting in } \\
\text { rapid percolation to the aquifer [35] and high-water evaporation from the soil to the } \\
\text { atmosphere }\end{array}$ \\
\hline Soil Heath Indicators & Effect of Climate Change \\
\hline Aggregate stability & $\begin{array}{l}\text { High temperature reduces aggregate stability and this exposes soil to soil erosion } \\
\text { agents like wind and water [35] }\end{array}$ \\
\hline Infiltration & $\begin{array}{l}\text { Wet conditions and heavy rain fall favor leaching and mineral go in deeper soil } \\
\text { layers where they cannot be reached by plants [6] }\end{array}$ \\
\hline Bulk density & $\begin{array}{l}\text { High temperature decreases soil bulk density and this exposes soil to both wind } \\
\text { and water erosion thus washing away soil nutrients and making soil less } \\
\text { supportive to plant growth [37]. }\end{array}$ \\
\hline Soil \& rooting depths & $\begin{array}{l}\text { High temperature makes soil compact and hard for soil roots to penetrate to } \\
\text { deeper layers and this minimizes water absorption by those plants with tap roots. }\end{array}$ \\
\hline $\begin{array}{l}\text { Soil available water \& } \\
\text { distribution }\end{array}$ & $\begin{array}{l}\text { High temperature decreases both surface and ground soil water availability which } \\
\text { interferes with plant growth and other ecosystem services provided by soil [22]. }\end{array}$ \\
\hline Soil surface cover & $\begin{array}{l}\text { Soil surface cover prevents moisture loss and this promotes soil health. It also } \\
\text { adds SOM to the soil hence enhancing soil fertility, structure thus prevents soil } \\
\text { erosion by wind or water [25]. }\end{array}$ \\
\hline
\end{tabular}

Soil health indicators (Table 1) respond to climate change effect differently in different landscapes and soil types.

\section{The Synergy Between Soil Health, Crop Production, Climate Change and Food Security}

Food security refers to a situation where all the people have access and affordability to all their required foods to meet their dietary needs for better heath and livelihoods [38-40]. Climate change affects soil structure, water holding capacity and nutrient cycling culminating into low crop production, thereby affecting food security of populations across the globe. Climate change promotes soil erosion, affects soil structure hence food and fibre production, which are necessary for human welfare [8]. Anthropogenic activities associated with land use that negatively affect soil health do not only affect climate but they also affect crop production which undermines food security across the globe. Unhealthy soils do not only produce less crop yields but also less nutritious foods for human consumption. Table 1 shows most crops that need healthy soils for providing important nutrients for human health required for enhancing food security. Climate change that affects soil health also affects food production and peoples' livelihoods.

Table 1 shows the daily global food sources and their respective Calories they provide thus contributing to food security. With exception of fish and aquatic products, the rest of foodstuffs, require good and healthy soils for improved productivity and will be either directly or indirectly affected by climate change. Heavy rains caused by climate change, cause soil erosion, affect crop production and result into food insecurity [8]. 
Table 1. Daily per capita food intake as a worldwide average, 2001-2003

(Adopted from Brevik, 2014)

\begin{tabular}{|l|c|c|}
\hline \multicolumn{1}{|c|}{ Food Source } & Calorie & Percent of Calories \\
\hline Rice & 557 & 25.5 \\
\hline Wheat & 521 & 23.9 \\
\hline Maize & 147 & 6.7 \\
\hline Sorghum & 33 & 1.5 \\
\hline Potatoes & 60 & 2.7 \\
\hline Cassava & 42 & 1.9 \\
\hline Sugar & 202 & 9.3 \\
\hline Soybean Oil & 87 & 4.0 \\
\hline Palm Oil & 50 & 2.3 \\
\hline Milk & 122 & 5.6 \\
\hline Animal Fats (raw and butter) & 62 & 2.8 \\
\hline Eggs & 33 & 1.5 \\
\hline Meat (pig) & 117 & 5.4 \\
\hline Meat (poultry) & 46 & 2.1 \\
\hline Meat (bovine) & 40 & 1.8 \\
\hline Meat (sheep and goats) & 11 & 0.5 \\
\hline Fish and other aquatic products ${ }^{\text {b }}$ TOTAL & 52 & 2.4 \\
\hline \multicolumn{2}{|c|}{ Aquatic products data from 2003. All other data from $2001-2003 ;{ }^{b}$} \\
Includes both marine and freshwater products.
\end{tabular}

\section{The Linkage Between Soil Health and Climate Smart Agriculture (CSA)}

Climate smart agriculture stands on three pillars i.e., increasing productivity and income; building resilience and adaptation to climate change and reducing greenhouse emissions to the atmosphere [41]. Healthy soils support the three pillars by promoting crop production thus increasing farmers' income; enhancement of adaptation and mitigation to climate change through carbon sequestration and building crop resilience to climate stresses. CSA approach is a climate smart soil health approach that aim at improving the wellbeing of the populations across the globe, especially in developing countries. Smart soils are those that sequester more carbon and mitigate climate change [42-43].

\section{The Effect of Climate Change on Soil Biodiversity}

Healthy soils are habitats for macrofauna which play a big role in carbon cycle [44]. They include pro, nematodes and collembola that play essential roles in a variety of ecosystem services including turnover of organic matter, nutrient mineralization and regulation of population densities. Neither too high nor too low temperature or rainfall favour such processes and moderate temperature and rainfall are required to preserve soil biodiversity and health so as to keep providing ecosystem services required for a healthy environment [45-46]. Chen et al (2019), pointed out that agricultural practices such as minimum or no till, addition of agriculture amendments and crop rotation have potential to enhance soil biodiversity thus keeping soils healthy and mitigating impacts of climate change [48].

\section{The contribution of soil health to Sustainable Development Goals (SDGs)}

Healthy soils Table 2 substantially contribute to the UN SDGs in regard to economic development, poverty eradication, clean water, reverse land degradation, conserve biodiversity loss and climate change adaptation and mitigation, and food security enhancement [49].

\section{Proposed strategies for improving soil health}

The Europian Commission [35] recommends the following management practices in agricultural landscape to maintain water retention capacity and keep soils healthy:

i. mitigating the impacts of the use of heavy machinery and heavy tillage to reduce soil compaction and avoid disturbance of soil structure

ii. mitigating the impact of tillage, through reduced tillage or tillage adapted to environmental conditions, such as contour tillage on slopes 
Table 2. Contribution of healthy soils to Sustainable Development Goals (adopted and modified from UNDP, 2015)

\begin{tabular}{|c|c|}
\hline Goal & Contribution of healthy soils \\
\hline $\begin{array}{l}\text { SDG } 1 \text {. End poverty in all its forms } \\
\text { everywhere }\end{array}$ & $\begin{array}{l}\text { Over } 80 \% \text { of most developed countries are employed in the } \\
\text { agriculture sector. Healthy soils enhance crop production and } \\
\text { boosts employment opportunities especially for development } \\
\text { counties thus contributing to poverty eradication [50] }\end{array}$ \\
\hline $\begin{array}{l}\text { SDG 2. End hunger, achieve food } \\
\text { security and improved nutrition and } \\
\text { promote sustainable agriculture }\end{array}$ & $\begin{array}{l}\text { Agriculture is the food basket for the billions of people across } \\
\text { the globe. It requires health soils to feed the world's population } \\
\text { projected to be } 9.1 \text { billion people by } 2050 \text { and meet their } \\
\text { nutritional demands [51] }\end{array}$ \\
\hline $\begin{array}{l}\text { SDG } 6 \text {. Ensure availability and } \\
\text { sustainable management of water } \\
\text { and sanitation for all }\end{array}$ & $\begin{array}{l}\text { Healthy soils play an important role in water filtration, improve } \\
\text { water quality and contribute to provision of safe water for } \\
\text { domestic use thus enhancement of hygiene among global } \\
\text { communities [52] }\end{array}$ \\
\hline $\begin{array}{l}\text { SDG 8. Promote sustained, } \\
\text { inclusive and sustainable economic } \\
\text { growth, full and productive } \\
\text { employment and decent work for } \\
\text { all }\end{array}$ & $\begin{array}{l}\text { Agriculture is a major source of income and household } \\
\text { development for most developing countries. Healthy soils } \\
\text { provide sustainable economic development and employment for } \\
\text { households in many countries [53] }\end{array}$ \\
\hline $\begin{array}{l}\text { SDG 13. Take urgent action to } \\
\text { combat climate change and its } \\
\text { impacts }\end{array}$ & $\begin{array}{l}\text { Health soils sequester more carbon from the atmosphere and } \\
\text { store it hence reducing concentration of } \mathrm{CO}_{2} \text { from the } \\
\text { atmosphere thus mitigating climate change impact. They } \\
\text { strengthen the resilience and adaptation capacity of landscapes } \\
\text { to climate-related hazards and natural disasters [49] }\end{array}$ \\
\hline $\begin{array}{l}\text { SDG 15. Protect, restore and } \\
\text { promote sustainable use of } \\
\text { terrestrial ecosystems, sustainably } \\
\text { manage forests, combat } \\
\text { desertification, and halt and } \\
\text { reverse land degradation and halt } \\
\text { biodiversity loss }\end{array}$ & $\begin{array}{l}\text { Healthy soils provide better ecosystem services such as } \\
\text { regulating and provisioning to the populations. They reduce soil } \\
\text { erosion and floods and support many flora and fauna species. } \\
\text { They contain better macro and micronutrients, and have higher } \\
\text { water holding capacity for supporting biodiversity and enhance } \\
\text { plant growth and development }[54,55]\end{array}$ \\
\hline
\end{tabular}

iii. promoting the return of organic matter to the soil, through organic amendment and crop residue management

iv. better integrating the issue of soil water retention when designing crop rotations and include legume-cereal rotations to enhance nutrients retention in degraded soils

v. maintaining landscape features such as hedges and buffer strips along rivers, which allow slowing down water flows, and reducing the size of patches to optimize the hydrological functioning of the catchment application of sustainable land management to boost crop production without damaging the environment through pollution

vi. growing cover crops and leaving land under permanent vegetation cover to enhance water retention and nutrient cycling for better productivity

vii. application of mulching that keeps soil moisture and soil structure for effective soil respiration and microbial activity

viii. application of fallowing to allow soils to rest and regain nutrients before the next growing seasons so as to boost crop yields ix. application of integrated crop-livestock farming that provide organic manure to the soils and keep them healthy for improved productivity

$x$ reduced application of artificial fertilizers and herbicides to minimize the effect on soil micro biodiversity which are essential in soil respiration

\section{Conclusions and Recommendations}

Climate change significantly affects soil health and peoples' livelihoods across the globe. High temperature and heavy precipitation affect soil health indicators and processes such as soil formation, soil structure, soil chemistry, soil porosity and soil biodiversity. This influences soil water holding capacity, soil fertility, crop production and consequently food security and improved livelihoods. Soil health contributes to the UN Sustainable Development Goals and peoples' wellbeing. Both soil health and climate change are complex phenomena that affect each other. Proper land management is essential for improving soil health, climate change mitigation and improvement of human well-being. Both developed and developing countries need to put deliberate efforts on improving 
soil heath, crop yields for improved livelihoods. The effect of soil health on human health and development needs to be studied.

\section{References}

[1] C. Werndl, on defining climate and climate change, The British Journal for the Philosophy of Science, 67 (2016) 337-364. [DOI]

[2] Woods End Laboratories, (2018) Perform Your Own Soil Health Suite, 1-2.

[3] B. P. Singh, A. L. Cowie, K. Y.Chan, (2011) Soil health and climate change, SpringerVerlag, Berlin Heidelberg.[DOI]

[4] A.Cano, A.Núñez, V. Acosta-Martinez, M. Schipanski, R. Ghimire, C. Rice, C. West, Current knowledge and future research directions to link soil health and water conservation in the Ogallala Aquifer region, Geoderma, 328 (2018) 109-118. [DOI]

[5] D. E. Allen, B. P. Singh, and R. C. Dalal, (2011) Soil Health Indicators Under Climate Change: A Review of Current Knowledge, Soil health and climate change, 25-46. [DOI]

[6] Meghan Sindelar, (2015) Soils and Climate, no. January. NCAR, 9-12.

[7] L. Parker, C. Bourgoin, A. Martinez-Valle, P. Läderach, Vulnerability of the agricultural sector to climate change: The development of a pan-tropical Climate Risk Vulnerability Assessment to inform sub-national decision making, PLoS One, 14 (2019) 1-25. [DOl]

[8] E. C. Brevik, The Potential Impact of Climate Change on Soil Properties and Processes and Corresponding Influence on Food Security, Agriculture, 3 (2013) 398-417. [DOl]

[9] L. B. Martínez-García, G. Korthals, L. Brussaard, H. B. Jørgensen, G. B. De Deyn, Organic management and cover crop species steer soil microbial community structure and functionality along with soil organic matter properties, Agriculture, Ecosystems \& Environment, 263 (2018) 7-17. [DOl]

[10] P. S. D. Frost, H. M. van Es, D. G. Rossiter, P. R. Hobbs, P. L. Pingali, Soil health characterization in smallholder agricultural catchments in India, Applied Soil Ecology, 138, (2019)171-180. [DOI]

[11] Meghan Sindelar, (2015) Soils and Climate,Soil science society of America, 9-12.
[12]

C. L.Walthall, J. Hatfield, P. Backlund, L. Lengnick, E. Marshall, M. Walsh, (1935) Climate change and agriculture in the United States, Effects and adaptation, USDA Technical Bulletin 1935. Washington, DC. 186 pages.

[13] A. Cai, W. Feng, W. Zhang, M. Xu, Climate, soil texture, and soil types affect the contributions of fi ne- fraction-stabilized carbon to total soil organic carbon in different land uses across China, Journal of Environmental Management, 172 (2016) 2-9. [DOI]

[14] R. Karmakar, I. Das, D. Dutta, A. Rakshit, Review Article Potential Effects of Climate Change on Soil Properties: A Review, Science international, 4 (2016) 51-73. [DOI]

[15] D. W. Hallema, A. N. Rousseau, S. J. Gumiere, Y. Périard, P. H. Hiemstra, L. Bouttier, A. Olivier, Framework for studying the hydrological impact of climate change in an alley cropping system, Journal of hydrology, 517 (2014) 547-556. [DOI]

[16] K. Paustian, J. Lehmann, S. Ogle, D. Reay, G. P. Robertson, P. Smith, Perspective Climatesmart soils, Nature, 532 (2016) 49-57. [DOl]

[17] G. P. Keth Paustian, Johaness Lehmann, Stephen Ogle, David Raey, P. S. Robertson, Edinburgh Research Explorer 'Climate-smart' soils : a new management paradigm for global agriculture, Nature, 532 (2016) 49-57. [DOI]

[18] Paul B. Thompson, David M. Kaplan, Encyclopaedia of Food and Agricultural Ethics, Encycl. Food Agric. Ethics, no. January, 2014, XXXVII, 1860.

[19] E. Alavaisha, S. Manzoni, R. Lindborg, Different agricultural practices affect soil carbon, nitrogen and phosphorous in Kilombero -Tanzania, Journal of environmental management, 234 (2018)159-166.[DOI]

[20] W. Tumwesigye, J. Wasige, G. Thomas, Effect of land use change and slope position on soil organic carbon in Kitabi Watershed Rwanda, Journal of Scientific and Innovative Research, 4 (2015) 213- 217.

[21] T. Searchinger, R. Heimlich, R. A. Houghton, F. Dong, A. Elobeid, J. Fabiosa, T. H. Yu, Use of US croplands for biofuels increases greenhouse gases through emissions from land-use change. Science, 319 (2008) 12381240. [DOI] 
[22] J. F. Soussana, S. Lutfalla, F. Ehrhardt, T. Rosenstock, C. Lamanna, P. Havlík, R. Lal, Matching policy and science: Rationale for the '4 per 1000-soils for food security and climate'initiative, Soil and Tillage Research, 188 (2019) 3-15.[DOI]

[23] V. de Paul Obade, Integrating management information with soil quality dynamics to monitor agricultural productivity, Science of the Total Environment, $651 \quad$ (2019) 20362043.[DOI]

[24] R. Karmakar, I. Das, D. Dutta, A. Rakshit, Potential Effects of Climate Change on Soil Properties: A Review, Science international, 4 (2016) 51-73. [DOI]

[25] J. Uusi-kämppä, R. Keskinen, J. Heikkinen, I. Guagliardi, V. Nuutinen, A map-based comparison of chemical characteristics in the surface horizon of acid and non-acid sulfate soils in coastal areas of Finland, Journal of Geochemical Exploration, 200 (2019) 193-200. [DOI]

[26] T. E. Lychuk, A. P. Moulin, R. L. Lemke, R. C. Izaurralde, E. N. Johnson, O.O. Olfert, S. A. Brandt, Climate change, agricultural inputs, cropping diversity, and environment affect soil carbon and respiration: A case study in Saskatchewan, Canada. Geoderma, 337 (2019) 664-678. [DOl]

[27] Z.Yao, D. Zhang, N. Liu, P.Yao, N. Zhao, Y. Li, $\mathrm{Y}$. Gao, Dynamics and sequestration potential of soil organic carbon and total nitrogen stocks of leguminous green manure-based cropping systems on the Loess Plateau of China, Soil and Tillage Research, 191 (2019) 108-116. [DOI]

[28] FAO, Climate change: implications for food safety," African Crop Science Journal, 12 (2017) 1-30.

[29] A. Damm, E. Paul-Limoges, E. Haghighi, C. Simmer, F. Morsdorf, F. D. Schneider, U. Rascher, Remote sensing of plant-water relations: An overview and future perspectives, Journal of plant physiology, 227 (2018) 3-19. [DOI]

[30] [30] Y. Zhang, W. Li, G. Sun, J. S. King, Coastal wetland resilience to climate variability: A hydrologic perspective, Journal of Hydrology, 568 (2018) 275-284. [DOl]
[31]

G. P. Wayne, (2013) The beginner's guide to representative concentration pathways, skeptical science, 1-25.

[32] A. K. Makarigakis, B. E. Jimenez-Cisneros, UNESCO's contribution to face global water challenges, Water, 11 (2019) 388. [DOI]

[33] D. Kaczan, A. Arslan, L. Lipper, (2013) Climate-Smart Agriculture? A review of current practice of agroforestry and conservation agriculture in Malawi and Zambia, ESA Working Paper Agricultural Development Economics Division Food and Agriculture Organization of the United Nations, 1-62.

[34] A. Delgado, J. A. Gómez, (2016) The soil. Physical, chemical and biological properties, In Principles of agronomy for sustainable agriculture, Springer, Cham, 15-26. [DOI]

[35] Europian Commission, Study on Soil and water in a changing environment, no. June. 2014.

[36] J. M. Kim, A. S. Roh, S.C. Choi, E.J. Kim, M.T. Choi, B.K. Ahn, H. Y. Weon, Soil pH and electrical conductivity are key edaphic factors shaping bacterial communities of greenhouse soils in Korea, Journal of Microbiology, 54 (2016) 838-845. [DOI]

[37] A. Kumar, A. Singh, Climate change and its impact on wheat production and mitigation through agroforestry technologies, International Journal on Environmental Sciences, 5 (2014) 73-90.

[38] T. Wossen, T.,Berger, M. G. Haile, C. Troost, Impacts of climate variability and food price volatility on household income and food security of farm households in East and West Africa, Agricultural systems, 163 (2018) 7-15. [DOI]

[39] L. Brussaard, P. Caron, B. Campbell, L. Lipper, S. Mainka, R. Rabbinge, M. Pulleman, Reconciling biodiversity conservation and food security: scientific challenges for a new agriculture, Current opinion in Environmental sustainability, 2 (2010) 34-42. [DOI]

[40] G. Branca, N. McCarthy, L. Lipper, M.C. Jolejole, (2011) Climate-Smart Agriculture: A Synthesis of Empirical Evidence of Food Security and Mitigation Benefits from Improved Cropland Management A Synthesis of Empirical Evidence of Food Security and Mitigation Benefits from Improved Cropland Management, Agriculture Organization of the United Nations (FAO), Italy. [Online]. Available: 
http://www.fao.org/docrep/015/i2574e/i2574e00 .pdf.

[41] Government of Zimbabwe, (2017) ClimateSmart Agriculture Manual for Zimbabwe, Climate Technology Centre and Network, Denmark.

[42] N. McCarthy, L. Lipper, G. Branca (2011) Climate-smart agriculture: smallholder adoption and implications for climate change adaptation and mitigation, Food and Agriculture Organization of the United Nations (FAO), Italy.

[43] B. M. Wekesa, O. I. Ayuya, J. K. Lagat, Effect of climate-smart agricultural practices on household food security in smallholder production systems: micro-level evidence from Kenya, Agriculture \& Food Security, 7 (2018) 114. [DOI]

[44] G. Vadakattu, G.W. Yeates, Soil microfauna as bioindica-tors of soil health, in: Biological Indicators of Soil Health, editedby: C. Pankhurst, and B.M. Doube, CABI, Wallingford, (1997) 201-234

[45] K. S. Zimmerer, S. de Haan, A. D. Jones, H. Creed-Kanashiro, M. Tello, M. Carrasco, Y. J. Olivencia, The biodiversity of food and agriculture (Agrobiodiversity) in the anthropocene: Research advances and conceptual framework, Anthropocene, 25 (2019) 100192. [DOI]

[46] FAO, "Biodiversity for Food and Agriculture Biodiversity for Food and Agriculture," 2011.

[47] C. Chenu, D. A. Angers, P. Barré, D. Derrien, D. Arrouays, J. Balesdent, Increasing organic stocks in agricultural soils: Knowledge gaps and potential innovations, Soil and Tillage Research, 188 (2017) 41-52. [DOI]

[48] S. Chen, D. Arrouays, D.A. Angers, C. Chenu, P. Barré, M. P. Martin, C. Walter, National estimation of soil organic carbon storage potential for arable soils: A data-driven approach coupled with carbon-landscape zones, Science of the Total Environment, 666 (2019) 355-367. [DOI]

[49] UNDP, "Sustainable Development Goals," 2015.

[50] L. Lipper, P. Thornton, B. M. Campbell, T. Baedeker, A. Braimoh, M. Bwalya, E. F. Torquebiau, Climate-smart agriculture for food security, Nature climate change, 4 (2014) 1068-1072. [DOI]
[51]

General Assembly, Resolution adopted by the General Assembly, General Assembly (2015) 1-35.

[52] United nations Economic Commission for Africa. African Climate Policy Centre; United Nations, Economic Commission for Africa. (2011-11). Climate change and water resources of Africa: challenges, opportunities and impacts. ACPC working paper; 5, $26 \mathrm{p}$ : Addis Ababa: (c) UN.ECA, http://hdl.handle.net/10855/21058

[53] D.R. Kanter, M. Musumba, S. L.Wood, C. Palm, J. Antle, P. Balvanera, S. Andelman, Evaluating agricultural trade-offs in the age of sustainable development, Agricultural Systems, 163 (2018) 73-88. [DOl]

[54] J. Ruane, (2019) Proceedings of the International Symposium on Agricultural Innovation for Family Farmers - Unlocking the potential of agricultural innovation to achieve the Sustainable Development Goals, Food and Agriculture Organization, Rome, Italy

[55] AU, "UNION COMMISSION AGENDA 2063 The Africa We Want FIRST TEN-YEAR IMPLEMENTATION PLAN 2014-2023." 2015.

\section{Funding}

No funding was received for conducting this study.

\section{Conflict of interest}

The authors have no conflicts of interest to declare that they are relevant to the content of this article.

\section{About the License}

(C) The author(s) 2021. The text of this article is open access and licensed under a Creative Commons Attribution 4.0 International License 